\title{
ENVIRONMENTAL PARAMETERS AND ANTIMICROBIAL SUSCEPTIBILITY OF ENTEROBACTERIACEAE ISOLATED FROM ESTUARINE WATERS OF SÃO VICENTE, SÃO PAULO STATE, BRAZIL
}

\author{
LOURENÇO N. G. G. S. (1), TAKAHASHI C. K. (1), LOPES T. F. (2), \\ LOPES C. A. M. (3)
}

(1) São Paulo State University, UNESP, São Vicente, São Paulo State, Brazil; (2) Santa Cecília University, Santos, São Paulo State, Brazil; (3) Department of Microbiology and Immunology, Botucatu Institute of Biosciences, São Paulo State University, UNESP, Botucatu, São Paulo State, Brazil.

ABSTRACT: Diseases transmitted by water consists a serious public health problem and enterobacteria are the main group of microorganisms responsible for outbreaks in humans. Such pathogenic bacteria proliferate in water polluted by domestic and industrial sewage and reach the population through seawater contact. The aim of the present work was to study environmental parameters as well as to identify Enterobacteriaceae species and their antimicrobial susceptibility in water samples collected from the estuarine area of São Vicente city (São Paulo State, Brazil). Strains were identified by using traditional biochemical tests described in literature and antimicrobial susceptibility tests were carried out using the disk diffusion method. Out of 26 samples, Escherichia coli was the most frequent species (40.1\%), followed by Citrobacter, Enterobacter and Klebsiella. The most effective drugs against the tested microorganisms were gentamycin, netilmicin, ciprofloxacin and cefepime. Since these bacteria are commonly found in seashore contaminated by sewage effluents, it can be concluded that estuarine waters of São Vicente are polluted and potentially capable of causing diseases and spreading pathogenic bacteria to human communities.

KEY WORDS: estuarine water, environmental parameters, Enterobacteriaceae, antimicrobial susceptibility.

CONFLICTS OF INTEREST: There is no conflict.

FINANCIAL SOURCE: CNPq/PIBIC.

CORRESPONDENCE TO:

CARLOS ALBERTO DE MAGALHÃES LOPES, Departamento de Microbiologia e Imunologia, Instituto de Biociências, UNESP, Campus de Botucatu, 18618-000, Botucatu, SP, Brasil. Email: lopescam@ibb.unesp.br. 
N. G. G. S. Lourenço et al. ENVIRONMENTAL PARAMETERS AND ANTIMICROBIAL SUSCEPTIBILITY OF ENTEROBACTERIACEAE ISOLATED FROM ESTUARINE WATERS OF SÃO VICENTE, SÃO PAULO STATE BRAZIL. J. Venom. Anim. Toxins incl. Trop. Dis., 2007, 13, 2, p. 473

\section{INTRODUCTION}

The increasing interest in scientific studies detecting pathogenic bacteria in seawater is due to the several outbreaks of infectious diseases originated from this source. The occurrence of such organisms in polluted waters mainly results from domestic and industrial effluents that alter the physical and chemical atmospheric conditions.

Aquatic ecosystems, which include freshwater (fountains, lakes, rivers), estuarine and oceanic waters, present an autochthonous microbial flora and other transitory microorganisms that arrived through the air, soil or industrial and domestic spill (10). Outbreaks of diseases transmitted by water can be caused by Enterobacteriaceae, which proliferate in polluted waters. However, industrial pollutants together with the residues and sewage from the Port of Santos and other close cities have led to a severe environmental degradation significantly reflecting in the social and public health areas.

The configuration of São Vicente's seafront, in a region that is not opened to the sea, hinders the circulation of water and the consequent dilution of pollutants, directly interfering in the seawater quality in some beaches. Several water courses that drain the main beaches of São Vicente are contaminated by sewage, and therefore directly influence the beaches quality, making them inappropriate for bath and leisure.

Sewage from several human activities has played an important role in the spread of pathogenic microorganisms to the environment and constitutes a risk to the public health (10). Additionally, bacteria resistant to antibiotics are spread at different densities to the atmosphere because of the crescent and frequent indiscriminate use of drugs in medicine, veterinary medicine and agricultural practices (3).

The lack of scientific research on the subject and the possibility that enterobacteria isolated from the sea environment are originated from coastal waters polluted by sewage and sanitary effluents make this study of great importance.

Analysis of the antimicrobial susceptibility profile of Enterobacteriaceae from São Vicente's estuarine waters can benefit the population by contributing to a better knowledge for the establishment of goals for its control. 
N. G. G. S. Lourenço et al. ENVIRONMENTAL PARAMETERS AND ANTIMICROBIAL SUSCEPTIBILITY OF ENTEROBACTERIACEAE ISOLATED FROM ESTUARINE WATERS OF SÃO VICENTE, SÃO PAULO STATE BRAZIL. J. Venom. Anim. Toxins incl. Trop. Dis., 2007, 13, 2, p. 474

\section{MATERIALS AND METHODS}

\section{Samples}

Twenty-six estuarine water samples were collected in $500 \mathrm{ml}$ flasks, previously sterilized within the standards of the American Public Health Association - APHA, 1995 (1), from August 2004 to May 2005, using a boat and a collector positioned at one-meter depth and 100 meters away from the estuary margin.

Sampling points were established at three different areas in São Vicente's estuarine system (Table 1) and recorded using Global Positioning System (GPS) equipment.

Table 1. Characterization of the sampling points in São Vicente's estuarine system, São Paulo State, Brazil.

\begin{tabular}{cll}
\hline Area of Sampling & São Vicente & \multicolumn{1}{c}{ estuary } \\
\hline Point 1 & $23^{\circ} 58^{\prime} 34^{\prime \prime S}$ & $46^{\circ} 24^{\prime} 14^{\prime \prime} \mathrm{W}$ \\
Point 2 & $23^{\circ} 58^{\prime} 42^{\prime \prime S}$ & $46^{\circ} 23^{\prime} 53^{\prime \prime} \mathrm{W}$ \\
Point 3 & $23^{\circ} 58^{\prime} 27^{\prime \prime S}$ & $46^{\circ} 23^{\prime} 36^{\prime \prime} \mathrm{W}$
\end{tabular}

Samples were kept cold and sent to Litoral Paulista Laboratories, UNESP, São Vicente, within 8 hours.

\section{Antimicrobial Susceptibility Test}

The isolation and identification of Enterobacteriaceae were carried out according to the traditional norms described by Koneman et al. (6) and Edwards \& Ewing (2). After species identification, the bacterial strains were stocked in Tryptic Soy Agar (Difco) for the antimicrobial susceptibility test.

Disks diffusion test was used following the criteria of the National Committee for Clinical Laboratory Standards - NCCLS, 2002 (7). The disks used (Sensifar®) and the respective concentrations were as follows: ampicillin (AP, 10 $\mu \mathrm{g}$ ), gentamycin

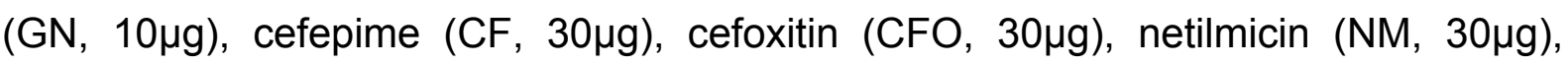

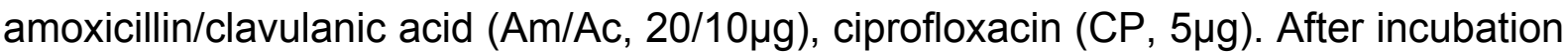
at $37^{\circ} \mathrm{C}$ for $24 \mathrm{~h}$, antimicrobial activity was evaluated by measuring the inhibition zone and interpreting data according to the NCCLS standards. 
N. G. G. S. Lourenço et al. ENVIRONMENTAL PARAMETERS AND ANTIMICROBIAL SUSCEPTIBILITY OF ENTEROBACTERIACEAE ISOLATED FROM ESTUARINE WATERS OF SÃO VICENTE, SÃO PAULO STATE BRAZIL. J. Venom. Anim. Toxins incl. Trop. Dis., 2007, 13, 2, p. 475

\section{RESULTS}

In the analysis period, there was a significant variation in the salinity indexes including a decrease in values from March 2005, while water temperature showed a slight variation (Fig. 1). The $\mathrm{pH}$ values were stable throughout the period. Environmental parameters ranged as follows:

a) Salinity: range, 16-34 ppm; mean, $26.84 \mathrm{ppm}$.

b) Temperature: range, $24-28^{\circ} \mathrm{C}$; mean, $26.05^{\circ} \mathrm{C}$.

c) $\mathrm{PH}$ : range, 7.3-8.2; mean, 7.84.

The bacterial strains $(n=142)$ characterized during the investigation corresponded to Escherichia coli (40.1\%), Enterobacter sp (15.5\%), Citrobacter freundii (14.8\%), Klebsiella pneumoniae (9.2\%), Morganella morganii (9.2\%), Proteus mirabilis (5.6\%), Proteus vulgaris (2.1\%), Citrobacter amalonaticus $(0.7 \%)$, Citrobacter sp $(0.7 \%)$, Enterobacter aerogenes (0.7\%), Providencia rettgeri $(0.7 \%)$, and Non-Fermenting Gram-Negative Bacilli - NFGNB (0.7\%).

Analysis of the antimicrobial activity of the tested drugs against the isolates showed gentamycin, netilmicin and ciprofloxacin with the highest activity (100\%), followed by cefepime $(97.3 \%)$, cefoxitin (84.2\%), amoxicillin/clavulanic acid (57.8\%), and ampicillin (47.3\%). 


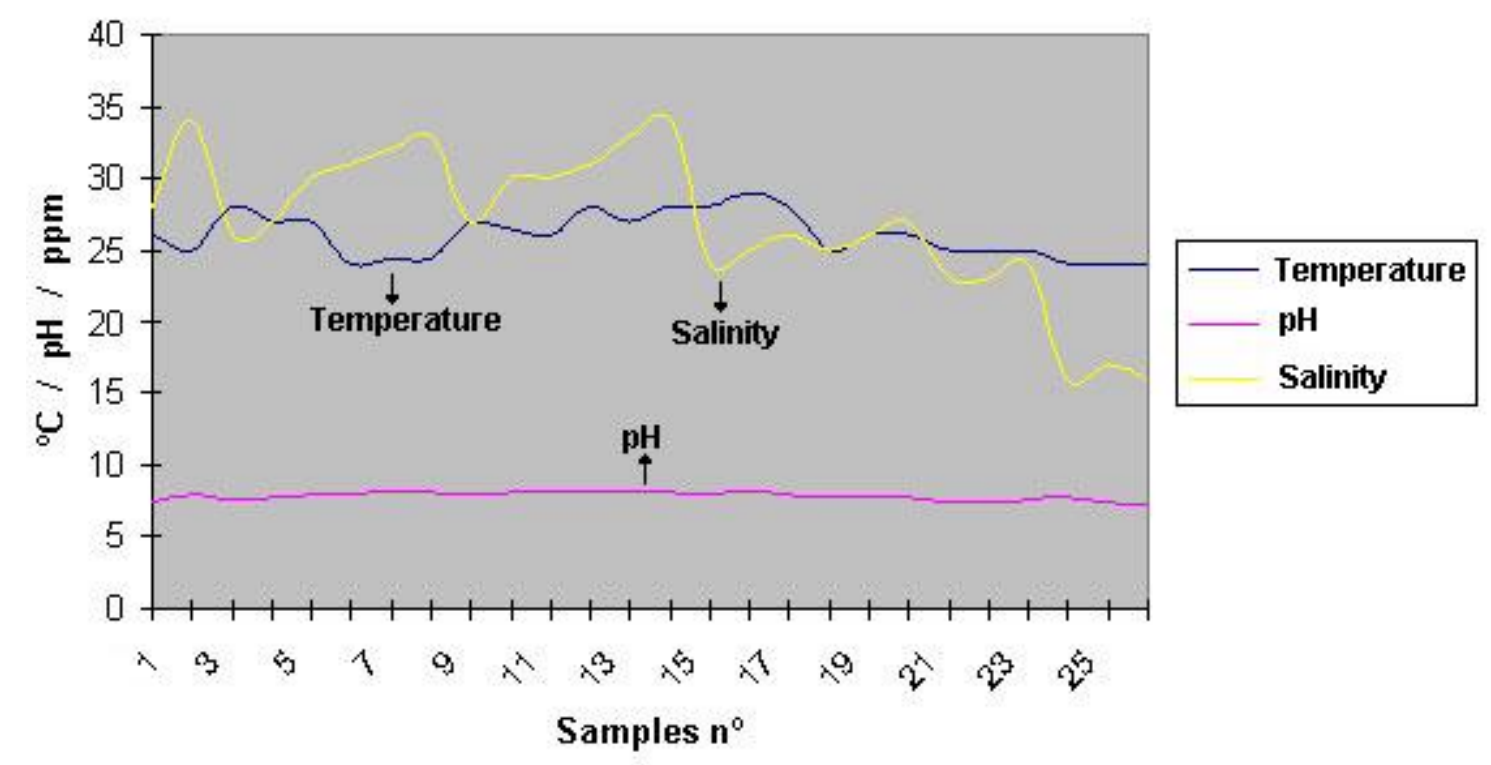

Figure 1. Variation in environmental parameters in estuarine waters of São Vicente's estuarine system, São Paulo State, Brazil.

Correlation between the samples numbers and periods:

Samples 1-3: Oct. 2004.

Samples 4-9: Nov. 2004.

Samples 10-12: Feb. 2005.

Samples 13-15: Mar. 2005.

Samples 16-18: Apr. 2005.

Samples 19-24: May 2005.

\section{DISCUSSION}

Environmental parameters of São Vicente's estuarine waters did not reveal significant variations, except for salinity, since the seasonal pluviometric indexes from November (2004) to May (2005) were significantly higher than in other periods.

The data obtained confirmed the presence of Enterobacteriaceae in the estuarine waters, especially Escherichia coli, a specific fecal pollution indicator which also constitutes a risk to human health $(9,10)$.

Fecal coliforms are frequently identified in tropical superficial waters, consisting of Escherichia, Klebsiella and Enterobacter or Citrobacter, the most common bacteria (4). Our data corroborated the studies carried out by CETESB $(11,12)$, which detected that Santos-São Vicente's estuarine system has been, for a long time, one of the most polluted areas in the São Paulo State seashore. 
N. G. G. S. Lourenço et al. ENVIRONMENTAL PARAMETERS AND ANTIMICROBIAL SUSCEPTIBILITY OF ENTEROBACTERIACEAE ISOLATED FROM ESTUARINE WATERS OF SÃO VICENTE, SÃO PAULO STATE BRAZIL. J. Venom. Anim. Toxins incl. Trop. Dis., 2007, 13, 2, p. 477

The contact with polluted water has been directly related to outbreaks of infections, as mentioned by Haile et al. (5), who observed an increase in the level of adverse risks to the health as a consequence of swimming practices in seawaters polluted by non-treated sewage.

Therefore, the treatment of effluents at the coastal sea area is extremely necessary, considering appropriate health conditions not only for the general population, but also for the coastal communities which accounts for the highest demographic density index in all seasonal periods. The urgency for the imposition of basic sanitary measures constitutes an effort that should be adopted by the public administration, as indicated by Pisciotta et al. (8).

In addition, the evaluation of the antibacterial drugs susceptibility allowed the observation of a significant profile, especially regarding gentamycin, netilmicin and ciprofloxacin. Resistance was slight to cefepime and cefoxitin, and amoxicillin/clavulanic acid and ampicillin were responsible for the highest percentages of resistant strains. Results revealed a predominance of bacteria resistant to $\beta$-lactamic drugs, which is worrying as such microorganisms can contribute, at the environmental level, to the spread of genetic markers to other bacteria as well as to the hindering of treatments with $\beta$-lactamic drugs, the antibiotics group most used in the control of infectious diseases. According to the World Health Organization (WHO), 80\% of the diseases that occur in developing countries are caused by water contamination and more than 15 million children aged 0-5 years old die every year (10).

\section{REFERENCES}

1 AMERICAN PUBLIC HEALTH ASSOCIATION. Standard methods for the examination of water and wastewater. 19.ed. Washington: American Public Health Association, 1995.

2 EDWARDS PR., EWING WH. Identification of Enterobacteriaceae. 4.ed. New York: Elsevier Publ., 1986.

3 GOÑI-URRIZA M., CAPDEPUY M., ARPIN C., RAYMOND N., CAUMETTE P., QUENTIN C. Impact of an urban effluent on antibiotic resistance of riverine Enterobacteriaceae and Aeromonas spp. Appl. Env. Microbiol. , 2000, 66, 125-32. 
N. G. G. S. Lourenço et al. ENVIRONMENTAL PARAMETERS AND ANTIMICROBIAL SUSCEPTIBILITY OF ENTEROBACTERIACEAE ISOLATED FROM ESTUARINE WATERS OF SÃO VICENTE, SÃO PAULO STATE BRAZIL. J. Venom. Anim. Toxins incl. Trop. Dis., 2007, 13, 2, p. 478

4 HAGLER AN., MENDONCA-HAGLER LC., SANTOS EA., FARAGE S., SILVA FILHO JB., SCHRANK A., OLIVEIRA RB. Microbial pollution indicators in Brazilian tropical and subtropical marine surface waters. Sci. Total Environ., 1986, 58, 151-60. 5 HAILE RW., WITTE JS., GOLD M., CRESSEY R., MCGEE C., MILLIKAN RC., GLASSER A., HARAWA N., ERVIN C., HARMON P., HARPER J., DERMAND J., ALAMILLO J., BARRETT K., NIDES M., WANG GY. The health effects of swimming in ocean water contaminated by storm drain runoff. Epidemiology, 1999, 10, 355-63.

6 KONEMAN EW., ALLEN SD., JANDA WM., SCHRECKENBERGER PC., WINN WC. Color Atlas and Textbook of Diagnostic Microbiology. 5.ed. Philadelphia: J.B. Linppicott, 1999. 840p.

7 NATIONAL COMMITTEE FOR CLINICAL LABORATORY STANDARDS. Performance standards for antimicrobial susceptibility testing. 15.ed. Informational Supplement M100-S15, 2002.

8 PISCIOTTA JM., RATH DF., STANEK PA., FLANERY DM., HARWOOD VJ. Marine bacteria cause false-positive results in the Colilert-18 rapid identification test for Escherichia coli in Florida waters. Appl. Environ. Microbiol., 2002, 68, 539-44.

9 RICE EW., ALLEN MJ., BRENNER DJ., EDBERG SC. Assay for $\beta$-glucuronidase in species of the genus Escherichia and its application for drinking-water analysis. Appl. Env. Microbiol., 1991, 57, 592-3.

10 RIVERA IG., MARTINS MT. Bactérias enteropatogênicas no ambiente aquático. Rev. Ciênc. Farm., 1996, 17, 115-36.

11 SÃO PAULO. CETESB. O sistema estuarino de Santos e São Vicente. São Paulo: CETESB, 2001. [Report].

12 SÃO PAULO. CETESB. Qualidade das Águas Litorâneas do Estado de São Paulo - Balneabilidade das Praias. São Paulo: CETESB, 2003. [Report]. 